\section{Grundig og gammeldags om evolusjon}

Tunstad E.

\section{Darwins teori}

Evolusjon gjennom 400 år. 405 s, ill. Oslo: Humanist forlag, 2009. Pris NOK 328 ISBN 978-82-92-62253-7

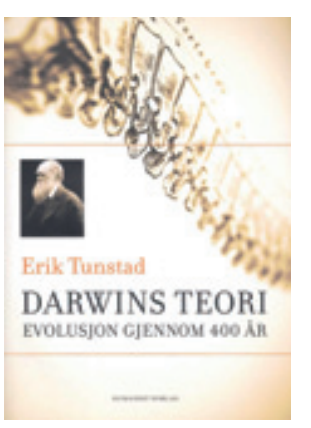

Alle norske skolebarn kjenner navnet Darwin. Men hvor mye vet vi egentlig om hans teorier? Darwins tur med Beagle er velkjent, likeledes analogien mellom apene og menneskene - men hvor mange kan egentlig uttale seg fyllestgjørende om hva evolusjonsteorien egentlig består i? Altfor ofte blir den servert overforenklet på et fat enten av teoriens bitreste fiender, som kreasjonistene, eller av (nesten like ille) nærmest misjonerende forkjempere. Fanatisme ligger ikke til forskningsjournalist og bio$\log$ Erik Tunstad, og han serverer da heller ikke evolusjonsteorien ferdigtygd for oss. Han har laget et solid arbeid om teoriens idéhistorie fra dens spede begynnelse frem til dagens forskning. I sluttkapitlet redegjør han for hvordan den er blitt misbrukt til å rettferdiggjøre alt fra rasehygiene til ekstremkapitalisme. Hans diskusjon av striden mellom naturvitere og kreasjonister i USA er tankevekkende og gir oss et innblikk i en politisk og religiøs kultur som heldigvis fremdeles er fremmed for oss.

Tunstad har satt seg godt inn i sekundærlitteraturen, og har god greie på de til dels kompliserte biologiske teoriene som har fulgt i kjølvannet av Darwins publikasjon om artenes opprinnelse. For vitenskapshistorikere er kappløpet mellom Alfred Russel Wallace (1823-1913) og Darwin velkjent, men antakelig ikke for flesteparten av Tunstads lesere. Darwin satt fremdeles etter flere tiårs arbeid og skrev på sitt storverk om artenes opprinnelse. En dag fant han så i posten sin egen teori, fiks ferdig i kortform, skrevet av en ung og fattig insektsamler, Alfred Russel Wallace. Tunstads fremstilling av forholdet mellom disse to som et dramatisk kappløp med en forsonlig slutt gir nerve til fortellingen, men er ikke nødvendigvis så opplysende.
Det interessante med evolusjonsteorien er dens paradokser: På den ene side tilbyr den et sammenhengende og logisk koherent syn på naturen, fra livet i dets enkleste form til det avanserte mennesket, på den annen side er denne utviklingen slett ikke rettlinjet, men består av tilfeldige tilpasningsprosesser som gjennom seleksjon driver utviklingen fremover.

Jeg tror nesten ikke det er mulig for oss å sette oss inn i hvilken effekt evolusjonsteorien hadde på midten av 1800-tallet. Midt i det puritanske århundret var det en skandale å sidestille menneskene med apene. Fremstillingen av Darwin som ape ble da også et yndet objekt for karikaturtegnerne. Ikke bare i biologiens historie, men i hele vår kulturs historie ble utgivelsen av Artenes opprinnelse et vannskille. Den gjorde noe grunnleggende med hva det ville si å være menneske. Disse aspektene er underlig fraværende hos Tunstad. Han diskuterer riktignok motstanden evolusjonsteorien møtte og fremdeles møter fra religiøst hold, men dette blir fremstilt som en teoretisk diskusjon. Hva betydde det så at hele grunnlagsfortellingen om menneskets opphav måtte skrives på nytt? Det får vi vite lite om.

Jeg er imponert over hva Tunstad har fått til med et så komplisert materiale. Likevel undrer det meg at han har valgt å skrive med vår tids etablerte sannheter som målestokk, spenningen bygges opp under hvor nær aktørene kom vår tids oppfatning av saksforholdet. Vitenskapshistorien har for lengst forlatt dette grepet fordi det gjør vold på det historiske materialet - og jeg tror Darwins teori ville ha stått seg langt bedre hvis han hadde forsøkt å finne ut hvorfor de tenkte på den måten de gjorde i stedet for å finne ut på hvilke punkter de tok feil.

Til slutt: Tunstad har fått mye godord for sin lettflytende prosa. Jeg synes den er sjenerende og ubehagelig. Det må være forlagets oppgave å ta ut språklige blødmer, utbrukte metaforer og muntlige upresisheter som «et rush av innsikt og inspirasjon», «Herfra glir historien rolig videre», «Hele smæla» eller «nå får vi nok en gang bruk for våre cellulære samarbeidspartnere eller var det slaver? - mitokondriene og kloroplastene». Liknende eksempler finnes på hver eneste side, og det passer dårlig når det er 400 av dem og rikelig med fotnoter. Til tross for dette - for den som liker vitenskapshistorie i gammel, evaluerende stil, er
Tunstads bok absolutt å anbefale nå i Darwin-året.

\section{Anne Kveim Lie}

Institutt for allmenn- og samfunnsmedisin Universitetet i Oslo

\section{Kosthold og evolusjon}

\author{
Mysterud I. \\ Mat, mennesket og evolusjon \\ 112 s. Oslo: Gyldendal Akademisk, 2006. \\ Pris NOK 265 \\ ISBN 978-82-05-36533-9
}

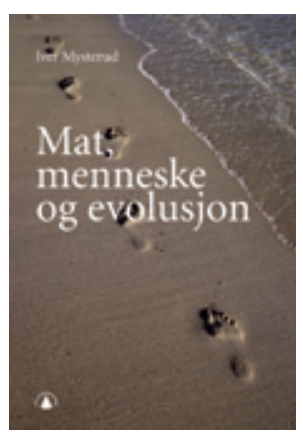

Menneskets genmateriale stammer fra en helt annen tid enn den vi lever i nå. Spørsmålet som reises av forfatteren er om våre gener er tilpasset vårt moderne kosthold og om mistilpasning kan være årsak til flere av

vår tids store sykdommer.

Mye tyder på at steinalderfolkets kosthold var variert, men fordi det på vesentlige punkter skiller seg fra dagens kosthold, argumenterer mange forskere for at forekomsten av flere kroniske sykdommer i moderne samfunn, som fedme, høyt blodtrykk, hjerte- og karsykdommer og diabetes, er en konsekvens av at vår art utviklet gener for å spise som jegere og sankere og ikke for å spise slik vi gjøre nå. Man mener at jegere og sankere foretrakk animalsk mat fremfor vegetabilsk mat, og at de foretrakk de feteste delene av dyr de hadde jaktet og drept. Menneskets store hjerne, som evoluerte for et par millioner år siden, er avhengig av et høyt inntak av fett, spesielt den ekstra lange omega-3-fettsyren dokosaheksaensyre (DHA), som kanskje var lettest tilgjengelig i strandsonen.

Denne lettleste, populærvitenskapelige boken gir mye stoff til ettertanke for både leg og lærd. Undertegnede er i denne forstand noe midt imellom. Som spesialist i fordøyelsessykdommer vil jeg kommentere følgende: Insulinom er en liten, vanligvis godartet svulst i bukspyttkjertelen som produserer insulin. Jeg er en av få klinikere som har sett slike pasienter og 
kunnet observere hvor utrolig kraftig fedmedrivende en høy insulinproduksjon er. $\AA$ forsøke å slanke disse pasientene ved hjelp av mosjon og diett er nytteløst. Situasjonen minner om det man ser hos mennesker som må opereres for sin fedme fordi andre måter å gå ned i vekt på ikke nytter. Jeg tror derfor at Mysterud og mange andre har rett når de mener at vårt høye karbohydratinntak er en vesentlig årsak til fedmeproblemet i vår tid. Problemene med laktoseintoleranse er etter min mening betydelig overdrevet, men jeg er enig $i$ at det er uforståelig at så mange voksne mennesker med laktase angivelig har melkeintoleranse.

Mysterud skriver at mennesket trenger en lang tarm for å skaffe nok næring, spesielt fett til den store hjernen. Det er sikkert riktig at fettabsorpsjonen er viktig for hjernefunksjonen, men fettabsorpsjonen trenger egentlig ikke så lang tarm, spesielt ikke lang tykktarm. Tykktarmen har lite eller ingenting med fettabsorpsjonen å gjøre og denne delen av tarmen kan vi operere bort uten at det făr konsekvenser for hjernefunksjonen. Tar vi bort for mye tynntarm derimot, kan man få hjerneskade, iallfall hvis kolesterolnivået blir lavt nok. Tykktarmen gjør at vi også skal kunne spise «gress»» (være «altetende», omnivor). Ca. $20 \%$ av karbohydratene blir ikke fordøyd og absorbert i tynntarmen, men går videre til tykktarmen hvor de blir mat for bakterier som produserer gass og korte fettsyrer. Disse korte fettsyrene absorberes og berger noe energi som ellers ville gå tapt. Bakeriene i tykktarmen kan raskt tilpasse seg et endret karbohydratinntak, og jeg er redd for at overfôring av disse bakteriene med «langsomme» karbohydrater som for en stor del går til tykktarmen, også kan gi fedme. Det er ti ganger så mange bakterier i tarmen som det er celler i hele kroppen og denne rasktvoksende bakteriefloraen har sikkert evoluert sine måter å signalisere til kroppen at de vil ha mer mat - for å leve videre. Hvordan bakteriene ev. signaliserer egen «sultfølelse» er ikke kjent, men tykktarmsflora som gir fedme, er nylig beskrevet hos mus.

Mysterud skriver: «Evolusjonstenkning er beklagelig nok ikke integrert i den ernæringslæren som predikes av ledende ernæringsforskere i vestlige land, dette gjelder også Norge. Rådene som gis kan være en direkte årsak til mange av de omfattende helse- og adferdsproblemene vi sliter med i vestlige land.» Dette er alvorlig, og jeg vil anbefale boken til alle som ønsker å orientere seg om evulosjonsteorier og deres mulige betydning for sunt kosthold. For dem som ønsker å fordype seg videre, finnes det 283 referanser.

Universitetet i Bergen

\section{Mikrober i åpent hav}

Helmreich S

\section{Alien ocean}

Anthropological voyages in microbial seas. 403 s, ill. Berkeley, CA: University of California Press, 2009. Pris USD 25

ISBN 978-0-520-25062-8

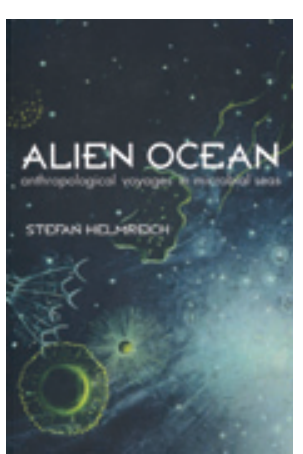

I den senere tid er det oppdaget at de åpne havområder inneholder uhorvelige mengder av mikroskopiske livsformer, kanskje 1000 ganger flere organismer per volumenhet enn forskere mente så sent som i 1980årene. Det er ikke bare antall individer som er høyt, også det biologiske mangfoldet er stort. Nye klasser organismer med overraskende stor genetisk og metabolsk variasjon oppdages kontinuerlig i vår tid. Hvor mange har for eksempel hørt om den nyoppdagede bakterien Prochlorococcus? Den er bare en mikrometer i omkrets, men tar igjen i antall hva den mangler i størrelse. Det er den mest vanlige fotosyntetiserende organisme på vår planet, og bidrar i vesentlig grad til karbonfiksering på Jorden. Fordi vi i så liten grad kjenner havets mest tallrike livsformer og deres økologiske betydning, er det fare for at vi i vår uvitenhet kan forårsake irreversible, alvorlige skader. Eksempler på dette er giftdumping, temperaturstigning, økende surhetsgrad og endringer i havstrømmer. Det er tross alt hav det er mest av på vår klode. Det er på denne bakgrunn vi må se bokens tittel, Alien ocean. Stefan Helmreich er ikke marinbiolog og heller ikke mikrobiolog. Hans fag er antropologi. Han skildrer liv og forskning ombord i dyptgående fartøyer og i marinbiologiske institutter på øyer i Stillehavet og i kystområder flere steder i verden. Boken bør leses som en samling frittstående essays og oversiktsartikler. En bonus er at vi blir kjent med så mange forskere og deres forskjellige syn på havets økologi.

Mikroorganismene kan grovt inndeles i tre hovedgrupper eller domener. Archae, tidligere kaldt archebakterier, omfatter bl.a. de ekstremofile mikrober og er evolusjonsmessig de eldste livsformer på kloden. De er metabolsk og strukturelt annerledes enn de egentlige bakterier, eubakterier, som er den andre hovedgruppen. Den tredje gruppen er eukaryoter som har distinkte cellekjerner. Ved hjelp av metoder som strømningscytometri og polymerasekjedereaksjoner kan vi nå utforske havets mikroskopiske liv og genetiske mangfold raskere og mer effektivt enn noen gang før. Molekyler fra bakterier i havet har vist seg å kunne drepe patogene mikrober og enkelte typer kreftceller. Flere av dem som kommer til orde i boken mener at mange av de mikrobegenomer som nå blir avslørt, representerer «økologigener» som kan bidra til å forklare dynamikken og interaksjonene mellom organismer. Havet ses på som et nettverk av gener. Overføring av gener mellom forskjellige arter skjer bl.a. ved hjelp av virus. Hvor nyttig en rent genetisk kartlegging av havet vil vise seg å være, er vel et åpent spørsmål. Det er tross alt hver enkelt mikrobes totale genkomplement som bestemmer dens fysiologiske responskapasitet og dens interaksjon med andre livsformer. Et spesielt problem som preger mye moderne forskning er den store analysekapasiteten. Den gir oss så mye informasjon at det blir mer enn vanskelig å sette sammen enkeltobservasjoner til forståelige fysiologiske og biokjemiske mønstre. Den overveldende mengden informasjon er i seg selv et økologisk problem. Noen informasjonsbrokker er viktigere enn andre, men hvilke det er, finner vi kanskje ut i seneste laget.

\section{Anton Hauge}

Avdeling for fysiologi

Institutt for medisinske basalfag

Universitetet i Oslo

\section{Dyrelivets utvikling}

Minelli A.

Perspectives in animal phylogeny \& evolution 345 s, tab, ill. Oxford: Oxford University Press, 2009. Pris GBP 35

ISBN 978-0-19-856621-2

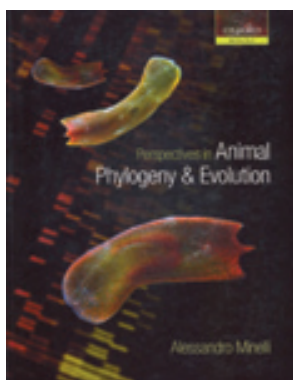

Alessandro Minelli er utviklingsbiolog ved universitetet i Padua. I denne boken slår han opp det helt store lerret, nemlig de flercellede dyrs struktur (phylogeny) og de utviklingsmekanismer som ligger

til grunn for strukturvariasjonene. Dette forskningsfeltet er under stadig endring, så Minelli bruker med rette ordet «perspectives» i boktittelen i stedet for en betegnelse som innebærer sikker kunnskap. Først omtales hver for seg evolusjonære mønstre og prosesser, i denne rekkefølgen. Det gir den interesserte leser et grunnlag for å forstå og følge hans mange eksempler på årsaks- og virkningskjeder både i utviklingen av det enkelte individs organer og utviklingen av nye arter.

Forfatteren stiller seg skeptisk til mange av de fylogenetiske trær med forgreninger 